Article

\title{
Optimisation of Growth of Raphidocelis subcapitata Immobilised for Biofuel Production: Influence of Alginate and $\mathrm{CaCl}_{2}$ Concentrations on Growth
}

\author{
Amel Benasla * and Robert Hausler \\ Station Expérimentale des Procédés Pilotes en Environnement, École de Technologie Supérieure, \\ Université du Québec, 1100, rue Notre-Dame Ouest Local A-1500, Montréal, QC H3C 1K3, Canada; \\ Robert.Hausler@etsmtl.ca \\ * Correspondence: amel.benasla.1@ens.etsmtl.ca; Tel.: +1-514-396-8800 (ext. 7541)
}

Received: 20 March 2018; Accepted: 15 May 2018; Published: 18 May 2018

\begin{abstract}
The growth of the green microalga Raphidocelis subcapitata in sodium alginate beads was studied. The beads were generated by the extrusion technique, which was followed by gelling in a $\mathrm{Ca}^{2+}$ solution. The alginate concentrations studied were $1 \%, 1.5 \%$ and $2 \%(w / v)$, while the concentrations of $\mathrm{CaCl}_{2}$ were $0.2 \%, 0.5 \%$ and $1 \%(w / v)$. The growth monitoring of the cells in the beads was performed by dissolving the gel in a sodium phosphate buffer and reading the optical density at $685 \mathrm{~nm}$ using a spectrophotometer. The results clearly showed that alginate and divalent $\mathrm{Ca}^{2+}$ ions do not contribute directly to the growth of microalgae but play a decisive role in preserving the integrity of the beads and protecting them from shrinkage. Furthermore, they have an important role in the transfer of nutrients, light and $\mathrm{CO}_{2}$ in the beads. The highest growth $\left(3.92 \times 10^{6} \pm 0.39\right.$ cells/bead) was obtained with the concentrations of alginate being $1.5 \%$ and $\mathrm{CaCl}_{2}$ being $0.2 \%$. However, the beads began to shrink and this resulted in the cells being released into the culture medium after the 8 th day. Of all the combinations studied, the combination of $2 \%$ alginate and $1 \% \mathrm{CaCl}_{2}$ was the best because it ensured the stability of the beads during the 10 days of culture and resulted in a low concentration of free cells detected in the culture medium. These concentrations were determined as the optimal conditions for the immobilization of microalgae and will be used in the following work.
\end{abstract}

Keywords: alginate; $\mathrm{CaCl}_{2}$; beads; Raphidocelis subcapitata; growth

\section{Introduction}

Climate change is the result of the industrialization of the planet and the massive use of fossil fuels [1-5]. This issue has stimulated the development of alternative and renewable energy sources, such as microalgae biomass [6,7]. Attention has been drawn to using microalgae for the production of biofuels for many reasons, including rapid growth. Some species can double their biomass 1-3 times in $24 \mathrm{~h}$ [8] due to high lipid productivity. Under certain conditions, they can accumulate $40-60 \%$ of their dry weight in fatty acids [9], and value in a very effective way the $\mathrm{CO}_{2}(1.83 \mathrm{~kg} \mathrm{CO} / \mathrm{kg}$ dry weight) [10]. Furthermore, their cultivation does not require the exploitation of agricultural land, unlike the production of biofuels from terrestrial cultures [11]. Dry biomass can be used to produce direct combustion energy [12], while the recovered heat can produce steam to activate turbines and generate electricity. The pyrolysis and the gasification of the microalgae make it possible to obtain the coal and the synthesis gas separately [13]. The latter can serve in turn to produce methanol, ethanol, dimethyl ether (DME), synthetic natural gas (SNG) and hydrogen [14].

By biochemical conversion, methane and ethanol can be produced from anaerobic biomass bio-anaerobic digestion or the fermentation of sugars accumulated in the cell [15]. This conversion 
system also allows for the production of hydrogen, with some microalgae having the capacity to produce hydrogen through enzymes, such as hydrogenases, during photosynthesis $[16,17]$. Finally, biodiesel can be obtained as follows [18]. First, the autotrophic culture requires a light source, $\mathrm{CO}_{2}$ and nutrients. The culture is optimized according to the selection of a strain, which involves adjustment of the culture conditions and promotion of the accumulation of lipids in the form of triglycerides. After this, the biomass is harvested and concentrated. Finally, the lipids are extracted and converted into biodiesel by a transesterification reaction. In this reaction, the triglycerides react with an alcohol, which is usually methanol, to form fatty acid esters (biodiesel) and glycerol as a by-product. Microalgae harvesting is a limiting step in the production of biofuels. According to some estimates, this accounts for $20-30 \%$ of the total cost of producing biodiesel [19]. These high costs are due to their very small diameter (2-20 $\mu \mathrm{m}$ in diameter) among other factors [20]. Centrifugation is the most frequently used method for separating cells from water [21]. However, it is a very energy-intensive technique and therefore, it contributes to an increase in the energy balance of the production process using algal biofuels [22]. More economical and more efficient methods of biomass concentration, such as the immobilization of microalgae in natural polysaccharides, such as alginates, carrageenans and agars, are currently being investigated worldwide. The latter has the advantage of non-toxicity, biocompatibility, biodegradability and light transparency, which maintain the photosynthetic activity of the algae [23-25]. Because of the particularly mild gelation conditions, alginates are the most favorable [26]. Alginate is a polycarboxylate extracted from brown algae, which gels by cationic bridging in the presence of multivalent ions, such as $\mathrm{CaCl}_{2}$ [27].

Although the immobilization of the photosynthetic microalgae in alginate beads has been the subject of previous studies $[23,25,28-31]$, a perfect mastery of this technology has not been achieved since it partially depends on the type of microorganism and its conditions of culture. In addition, it should be noted that the immobilization within matrices often causes limitations in the material transfer [32]. It is with this in mind that this study was undertaken. The main objective of this present study is to optimize the growth of Raphidocelis subcapitata in the alginate gel. This species has many advantages. Due to its high lipid productivity, it holds good potential in the field of energy-rich biomass $[33,34]$. Moreover, by fixing the $\mathrm{CO}_{2}$ in the form of organic matter due to its luminous energy, it is a potential candidate for decreasing $\mathrm{CO}_{2}$ in the atmosphere [35]. For this, we initiated the research by evaluating the effects of alginate and $\mathrm{CaCl}_{2}$ concentrations on the growth of the algae. The results obtained would allow us to determine the optimal conditions of immobilization for obtaining an important quantity of microalgae in order to produce the biodiesel.

\section{Materials and Methods}

\subsection{Chemicals and Reagents}

Sodium alginate from the brown algae (No. 71238) was used in this study for the formulation of beads. It was supplied by Sigma-Aldrich ${ }^{\circledR}$ (St. Louis, MO, USA).

Calcium chloride dihydrate $\mathrm{CaCl}_{2} \cdot 2 \mathrm{H}_{2} \mathrm{O}$ (No. 700912) was chosen to constitute the gelling medium. The divalent $\mathrm{Ca}^{2+}$ cation has a high affinity for polysaccharides of negative charges [27,36-38] compared to all monovalent cations. It was supplied by Anachemia.

Sodium phosphate monobasic dihydrate $\mathrm{NaH}_{2} \mathrm{PO}_{4} \cdot 2 \mathrm{H}_{2} \mathrm{O}$ (No. 71505) and sodium phosphate dibasic dihydrate $\mathrm{Na}_{2} \mathrm{HPO}_{4} \cdot 2 \mathrm{H}_{2} \mathrm{O}$ (No. 71643) were used to prepare the sodium phosphate buffer for dissolving the beads. They were obtained from Sigma-Aldrich ${ }^{\circledR}$.

Distilled water was used for the various manipulations.

\subsection{Microalga and Culture Medium}

The unicellular green algae Raphidocelis subcapitata was obtained from the Environment Canada Laboratory. The cells were conserved and grown in a medium [39] with five nutrient mother solutions having the following composition (per liter): (1) $25.5 \mathrm{~g} \mathrm{NaNO}_{3}$; (2) $14.7 \mathrm{~g} \mathrm{MgSO}_{4} \cdot 7 \mathrm{H}_{2} \mathrm{O}$; (3) $1.044 \mathrm{~g}$ 
$\mathrm{K}_{2} \mathrm{HPO}_{4}$; (4) $15 \mathrm{~g} \mathrm{NaHCO}_{3}$; (5) $10 \mathrm{~g} \mathrm{MgCl} \cdot 6 \mathrm{H}_{2} \mathrm{O} ; 4.4 \mathrm{~g} \mathrm{CaCl}_{2} \cdot 2 \mathrm{H}_{2} \mathrm{O} ; 0.185 \mathrm{~g} \mathrm{H}_{3} \mathrm{BO}_{3} ; 0.416 \mathrm{MnCl}_{2} \cdot 4 \mathrm{H}_{2} \mathrm{O}$; $3.28 \mathrm{mg} \mathrm{ZnCl} 2 ; 0.16 \mathrm{~g} \mathrm{FeCl}_{3} ; 1.428 \mathrm{mg} \mathrm{CoCl} 2 \cdot 6 \mathrm{H}_{2} \mathrm{O} ; 7.26 \mathrm{mg} \mathrm{Na} 2 \mathrm{MoO}_{4} \cdot 2 \mathrm{H}_{2} \mathrm{O} ; 0.012 \mathrm{mg} \mathrm{CuCl} ;$ and $0.3 \mathrm{~g}$ $\mathrm{Na}_{2}$ EDTA $2 \mathrm{H}_{2} \mathrm{O}$. From each solution, $1 \mathrm{~mL}$ was taken and placed in an Erlenmeyer flask, before the volume was brought to 1 liter by the addition of distilled water. The $\mathrm{pH}$ of the medium was adjusted to 7.5. The culture medium was autoclaved at $121^{\circ} \mathrm{C}$ for $20 \mathrm{~min}$.

\subsection{Algae Immobilization}

The immobilization of $R$. subcapitata cells in alginate beads was carried out according to the method of Moreira dos Santos et al. [40], with some modifications in the alginate/ $\mathrm{NaCl}$ ratio.

A pellet of microalgae resulting from the concentration of $100 \mathrm{~mL}$ of exponential growth cell density growth of about $10^{7}$ cells $/ \mathrm{mL}$ was washed three times in sterile saline water $(0.85 \%)$, with centrifugation of the sample between each wash $\left(4000 \mathrm{rpm}, 4{ }^{\circ} \mathrm{C}\right.$ for $\left.10 \mathrm{~min}\right)$. The cells were resuspended in $50 \mathrm{~mL}$ of sterile saline $(0.85 \%)$. After this, the algae suspension was mixed with $50 \mathrm{~mL}$ of the sodium alginate solution at the final concentrations of $1 \%, 1.5 \%$ and $2 \%$, which was previously sterilized by autoclaving $\left(120^{\circ} \mathrm{C}, 20 \mathrm{~min}\right)$, and gently homogenized. Each mixture was dripped from a $20 \mathrm{~mL}$ syringe equipped with a $0.9 \times 40 \mathrm{~mm}$ G needle (Braun, Melsungen, Germany) in $\mathrm{CaCl}_{2}$ solutions at the final concentrations of $0.2 \%, 0.5 \%$ and $1 \%$. These were previously sterilized by autoclaving $\left(121^{\circ} \mathrm{C}, 20 \mathrm{~min}\right)$, with gentle and constant agitation. The beads obtained were left in the $\mathrm{CaCl}_{2}$ solution for $30 \mathrm{~min}$ to complete the gelation reaction. After this, they were collected in a sterile metal sieve and then rinsed with sterile distilled water.

\subsection{Culture Conditions}

Cultures were performed in 2-L Erlenmeyer flasks, which were sterilized by the autoclave $\left(121^{\circ} \mathrm{C}\right.$, $20 \mathrm{~min}$ ). The beads containing the microalgae were aseptically introduced into $1 \mathrm{~L}$ of sterile culture medium. A thermoregulated chamber equipped with a stirring table (INFORS HT Ecotron) was used to provide standard culture conditions at a certain temperature $\left(25 \pm 1^{\circ} \mathrm{C}\right)$ and level of agitation (100 rpm).

The light was provided by a white fluorescent lamp (KF15T8CW-PROJECT PAK 15W) placed vertically in the cultures, providing illumination of 4000-5000 lux (light quantum flux of approximately $\left.56 \mu \mathrm{mol} /\left(\mathrm{m}^{2} \cdot \mathrm{s}\right)\right)$. The cultures were incubated under a photoperiod of $24 \mathrm{~h}$ of light for $0 \mathrm{~h}$ of darkness (24/0; L/D).

The contribution of $\mathrm{CO}_{2}$ was provided by an air pump (MARINA 300). The cultures were strongly bubbled (145 L of air/liter of culture/hour). The air was filtered through a $0.45-\mu \mathrm{m}$ porosity filter (Fischer Scientific, Hampton, NH, USA).

\subsection{Growth Monitoring}

The growth monitoring of the cells immobilized on the beads requires the prior dissolution of the gel. In this study, the sodium phosphate buffer was used to dissolve the beads, while the ion exchange between the $\mathrm{Na}^{2+}$ ions present in the buffer solution and the $\mathrm{Ca}^{2+}$ ions that were bound to the alginate leads to the destruction of the gel. During the ion exchange process, the content of free carboxylate anions in the gel increases, which leads to electrostatic repulsion between the alginate chains, causing relaxation of the chain. The beads begin to disintegrate when the alginate networks are unable to retain the structure and finally, they dissociate [41].

Each day, the 10 beads of each formula were removed aseptically from the Erlenmeyer flask and placed in $4 \mathrm{~mL}$ of sodium phosphate buffer $(\mathrm{pH}=6.0)$, which was previously sterilized by autoclaving. This achieved a final concentration of $50 \mathrm{mM}$. After this, they were incubated at room temperature for $4 \mathrm{~h}$. The number of cells was determined by measuring the optical density at $685 \mathrm{~nm}$ using a spectrophotometer (Varian cary 300 bio visible UV spectrophotometer). The relationship between $\mathrm{OD}_{685}(\mathrm{y})$ and cell concentration $(\mathrm{x})$ of $R$. subcapitata was established by a linear regression: $\mathrm{y}=0.3572 \mathrm{x}$ $\left(R^{2}=0.9978\right)$. The experiment was stopped when the stationary phase was reached. 


\subsection{Calculation of Growth Rate and Generation Time}

The growth rate was calculated as follows [42].

The culture of microalgae was carried out in batches. In this case, a material balance between the instants $t$ and $t+d t$ gives:

$$
\mathrm{VdX}=\mathrm{rVdt}
$$

where: $\mathrm{V}=$ volume of culture $(\mathrm{mL}) ; \mathrm{r}=$ growth rate $(\mathrm{cell} / \mathrm{mL} / \mathrm{d}) ; \mathrm{X}=$ cell concentration $(\mathrm{cell} / \mathrm{mL})$.

The growth rate of microalgae is given by the model:

$$
\mathrm{R}=\mu \mathrm{X}
$$

with: $\mu=$ specific growth rate $\left(\right.$ day $\left.^{-1}\right)$.

Using Equation (2), we obtain the following:

$$
\frac{d X}{d t}=\mu X
$$

If we consider all the culture phases, $\mu$ is not constant. However, in the exponential phase, $\mu$ is optimal and constant. This results in:

$$
\frac{\mathrm{dX}}{\mathrm{X}}=\mu \mathrm{dt}
$$

By integrating Equation (4), we obtain the following:

$$
\operatorname{Ln}=\frac{x}{x_{0}}=\mu\left(t-t_{0}\right)
$$

where: $\mathrm{t}_{0}$ : initial time; $\mathrm{x}_{0}$ : cell concentration corresponding $\mathrm{t}_{0}$.

The generation time is the time needed to double a population. It was calculated according to the following formula [42]:

$$
\mathrm{G}=\mathrm{Ln}_{2} / \mu
$$

where $G$ is the generation time (day); Ln is the natural logarithm; and $\mu$ is the specific growth rate $\left(\right.$ day $\left.^{-1}\right)$.

\section{Results and Discussion}

\subsection{Beads Analysis}

Before immobilizing the microalgae, we first sought to determine the concentrations of polymers and gelling agents for generating macroscopically homogeneous beads. For this, alginate and $\mathrm{CaCl}_{2}$ concentrations were chosen arbitrarily and the ball manufacturing tests were performed. The results obtained are summarized in Table 1, which were the average from three replicate experiments.

It has been found that both constituents (alginate and $\mathrm{CaCl}_{2}$ ) generated beads regardless of their concentrations, except for the $3 \%$ alginate solution $(\mathrm{m} / \mathrm{v})$. At this concentration of alginate solution, the formation of beads was almost impossible because the dissolution of alginate in water was very difficult even with the heating.

The $2.5 \%$ alginate solution generated beads of larger diameters than the other concentrations. However, the high viscosity of this solution interfered with its flow and high pressures were applied to make the beads. In addition, the latter had a non-regular shape.

In view of these results, the $2.5 \%$ and $3 \%$ alginate concentrations were considered unsuitable for the elaboration of the beads and were therefore not used in the following experiments. 
Table 1. Size of beads $(\mathrm{mm})$ versus alginate and $\mathrm{CaCl}_{2}$ concentrations.

\begin{tabular}{cccc}
\hline \multirow{2}{*}{ Alginate $\%(w / v)$} & \multicolumn{3}{c}{$\mathrm{CaCl}_{\mathbf{2}} \%(\boldsymbol{w} / v)$} \\
\cline { 2 - 4 } & $\mathbf{0 . 2}$ & $\mathbf{0 . 5}$ & $\mathbf{1}$ \\
\hline 1 & $3.0 \pm 0.2$ & $2.5 \pm 0.1$ & $2.0 \pm 0.1$ \\
1.5 & $3.5 \pm 0.2$ & $3.0 \pm 0.1$ & $2.5 \pm 0.1$ \\
2 & $3.8 \pm 0.2$ & $3.5 \pm 0.2$ & $3.0 \pm 0.1$ \\
2.5 & $3.8 \pm 0.2$ & $3.8 \pm 0.2$ & $3.5 \pm 0.2$ \\
3 & - & - & - \\
\hline
\end{tabular}

Increasing the alginate concentration and decreasing the $\mathrm{CaCl}_{2}$ concentration increases the size of the beads (Figure 1).

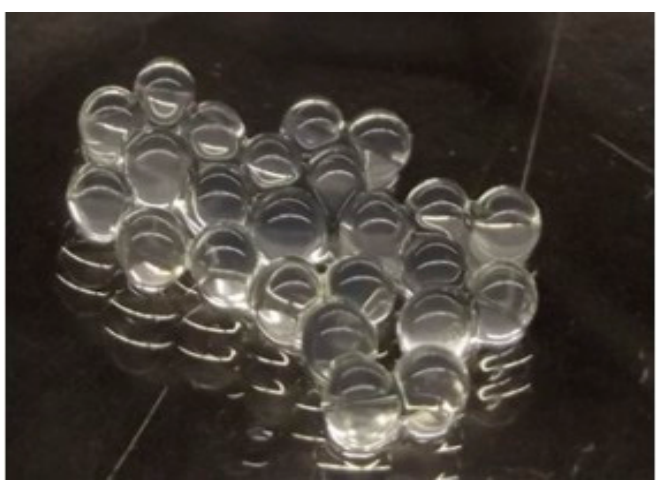

(a)

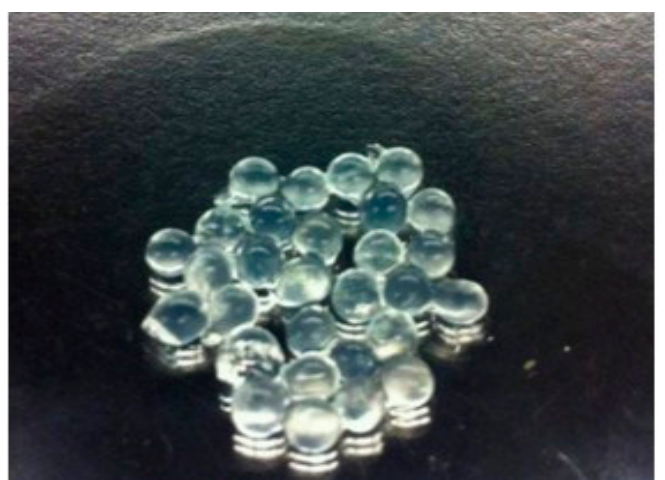

(b)

Figure 1. Macroscopic appearance of the sodium alginate beads with the following concentrations of: (a) $2 \%$ alginate and $0.2 \% \mathrm{CaCl}_{2}$; and (b) $1 \%$ alginate and $1 \% \mathrm{CaCl}_{2}$.

These observations are consistent with the findings of other articles. In 1985, Boyaval et al. [43] obtained beads with a diameter of $3.5 \mathrm{~mm}$ using a concentration of $2.5 \%$ alginate and $0.5 \% \mathrm{CaCl}_{2}$. This present study reports a slightly higher value of $3.8 \pm 0.2 \mathrm{~mm}$ for the same concentrations of alginate and $\mathrm{CaCl}_{2}$. Other authors obtained lower average diameters of $2.5 \mathrm{~mm}$ [44] and $2.6 \mathrm{~mm} \mathrm{[45].}$

The differences observed with the literature could be attributed to the types of alginates and extrusion devices used.

\subsection{Effects of Alginate and $\mathrm{CaCl}_{2}$ Concentrations on R. subcapitata Growth}

Figure 2 shows the evolution of the cellular concentrations of $R$. subcapitata in the alginate beads along the batch culture, according to the different concentrations of alginate and $\mathrm{CaCl}_{2}$ studied, over a period of 10 days. The experiments were performed in duplicate. The initial concentrations of microalgae cells, which varied between $2.6 \times 10^{5} \pm 0.26$ and $3 \times 10^{5} \pm 0.3$ cells/bead, were recorded inside the beads for all formulations. After a lag phase of three days, the $\mathrm{OD}_{685 \mathrm{~nm}}$ measured using the spectrophotometer revealed a significant increase in the microalgae concentrations inside the beads made from all the formulations. 


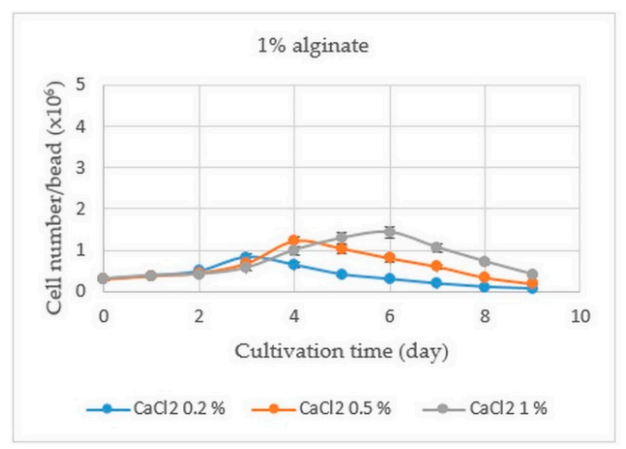

(a)

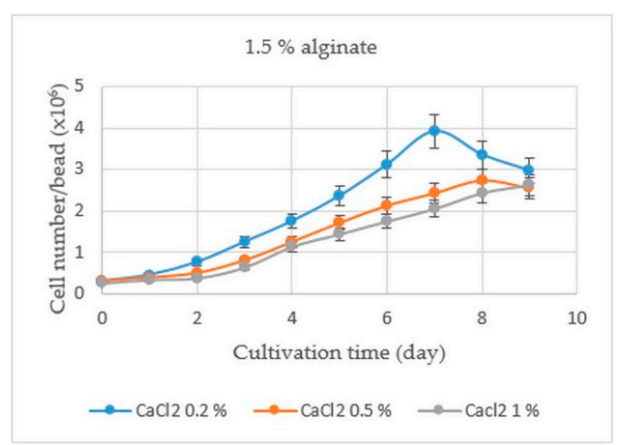

(b)

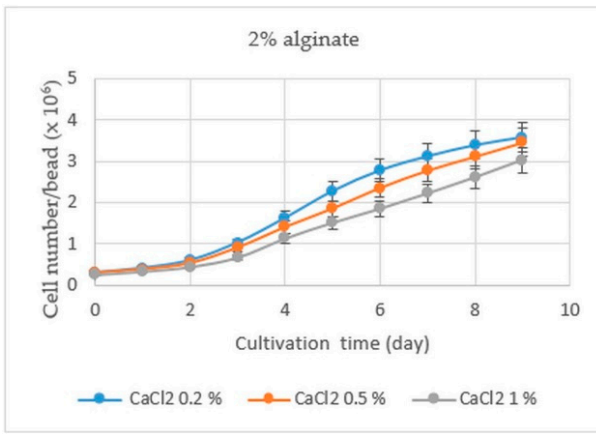

(c)

Figure 2. Evolution of the cellular concentrations of R. subcapitata in alginate beads according to the different concentrations of alginate and $\mathrm{CaCl}_{2}$ studied, over a period of 10 days: (a) $1 \%$ alginate; (b) $1.5 \%$ alginate; and (c) $2 \%$ alginate. $t=0$ corresponds to the first day of culture.

The beads made from the $1.5 \%$ and $2 \%$ alginate solutions (Figure $2 b, c$ ) exhibited remarkably higher concentrations of microalgae compared to the $1 \%$ alginate beads (Figure 2a) regardless of the $\mathrm{CaCl}_{2}$ concentrations used. The maximum concentrations of the cells reached within the beads of each formulation are presented in Table 2.

The beads formed from the 1\% alginate solution (Figure 2a) were soft and easily dissolved, showing inadequate results after day 4,5 , and 7 for $0.2 \%, 0.5 \%$, and $1 \% \mathrm{CaCl}_{2}$, respectively. The beads began to shrink and resulted in the release of cells into the culture medium. A high number of free cells were recorded on the 10th day (Table 3).

Table 2. Maximum concentrations of $R$. subcapitata (cells/bead $\times 10^{6}$ ) reached in the beads as a function of the alginate and $\mathrm{CaCl}_{2}$ concentrations.

\begin{tabular}{cccc}
\hline \multirow{2}{*}{ Alginate\% $(w / v)$} & \multicolumn{3}{c}{$\mathrm{CaCl}_{\mathbf{2}} \%(\boldsymbol{w} / v)$} \\
\cline { 2 - 4 } & $\mathbf{0 . 2}$ & $\mathbf{0 . 5}$ & $\mathbf{1}$ \\
\hline 1 & $0.83 \pm 0.08$ & $1.21 \pm 0.12$ & $1.48 \pm 0.35$ \\
1.5 & $3.92 \pm 0.39$ & $2.74 \pm 0.27$ & $2.62 \pm 0.26$ \\
2 & $3.58 \pm 0.35$ & $3.46 \pm 0.34$ & $3.04 \pm 0.3$ \\
\hline
\end{tabular}

Table 3. Free $R$. subcapitata concentrations (cells $/ \mathrm{mL} \times 10^{6}$ ) detected in the culture medium on the 10th day.

\begin{tabular}{cccc}
\hline \multirow{2}{*}{ Alginate\% $(w / v)$} & \multicolumn{3}{c}{$\mathrm{CaCl}_{\mathbf{2}} \%(\boldsymbol{w} / \boldsymbol{v})$} \\
\cline { 2 - 4 } & $\mathbf{0 . 2}$ & $\mathbf{0 . 5}$ & $\mathbf{1}$ \\
\hline 1 & $1.54 \pm 0.15$ & $1.28 \pm 0.12$ & $1.0 \pm 0.1$ \\
1.5 & $0.8 \pm 0.08$ & $0.34 \pm 0.03$ & $0.21 \pm 0.02$ \\
2 & $0.27 \pm 0.02$ & $0.16 \pm 0.01$ & $0.12 \pm 0.01$ \\
\hline
\end{tabular}


These observations have shown that a low concentration of alginate causes the instability of the beads due to the thin layer of the formed biofilm. Furthermore, the $\mathrm{Ca}^{2+}$ ions play an important role in the hardening of the beads and in the maintenance of their stability for a long time. Low $\mathrm{CaCl}_{2}$ concentrations reduce the stability of the beads, which causes them to easily release the cells into the culture medium. Thus, a $1 \%$ concentration of alginate is certainly not suitable for the culture of microalgae in the beads for a long time.

The formulation based on $1.5 \%$ alginate (Figure $2 \mathrm{~b}$ ) allowed for good growth of the microalgae. Nevertheless, a shrinkage of the beads formed from $0.2 \%$ and $0.5 \% \mathrm{CaCl}_{2}$ solutions was observed after the 8 th and 9 th day, respectively. The $0.1 \%$ concentration of $\mathrm{CaCl}_{2}$ allowed us to maintain the stability of the beads during the 10 days of culture. In addition, the free cells detected on the 10th day were reduced compared to the beads from $1 \%$ alginate (Table 3 ).

The beads synthesized with the $2 \%$ alginate solution (Figure $2 \mathrm{c}$ ) demonstrated a continuous growth of microalgae even after the exponential growth phase, without remarkable shrinkage of the beads. Furthermore, the free cell concentrations recorded on the 10th day of culture were considerably minimized (Table 3). There was a maximum reduction of $40 \%$ compared to those synthesized using $1.5 \%$ alginate, while the maximum reduction was $88 \%$ when compared to those produced using $1 \%$ alginate for the same concentration of $\mathrm{CaCl}_{2}(1 \%)$.

In a second step, the growth rates (Table 4 and Figure 3) and the generation times (Table 4) obtained from all the formulations tested were compared in order to fulfil the objective of this present study, which was the optimization of the growth rate of the alga to obtain a large quantity of cells to produce biodiesel. The results obtained showed that the beads made with the combination of $1 \%$ alginate and $1 \% \mathrm{CaCl}_{2}$ had the lowest growth rate and therefore, the slowest growth $(\mu=0.17 \pm 0.01$ cells/bead/day, $\mathrm{G}=4.05 \pm 0.4$ days) of all the combinations studied.

On the other hand, the growth rate values recorded with the beads from the $1.5 \%$ and $2 \%$ alginate solutions and the studied concentrations of $\mathrm{CaCl}_{2}$ indicated that the highest growth rate was obtained with the formulation of $1.5 \%$ alginate and $0.2 \% \mathrm{CaCl}_{2}(\mu=0.27 \pm 0.2 \mathrm{cells} / \mathrm{bead} /$ day, $\mathrm{G}=2.55 \pm 0.25$ days). These concentrations of alginate and $\mathrm{CaCl}_{2}$ appear to improve the mass transfer of nutrients, light and $\mathrm{CO}_{2}$ in the beads due to the relatively thin layer of alginate biofilm formed and the soft texture of the beads. However, they were not sufficient to ensure the stability of the beads for a long time; it is the same for the concentrations of alginate $1.5 \%$ and $\mathrm{CaCl}_{2} \mathrm{0.5} \%$.

Table 4. Growth Rates (Cells/Bead/Day) and Generation Time (Day) of R. subcapitata as a function of the concentrations of alginate and $\mathrm{CaCl}_{2}$.

\begin{tabular}{|c|c|c|c|c|c|c|}
\hline \multirow{3}{*}{$\mathrm{CaCl}_{2} \%(w / v)$} & \multicolumn{6}{|c|}{ Alginate $\%(w / v)$} \\
\hline & \multicolumn{2}{|c|}{1} & \multicolumn{2}{|c|}{1.5} & \multicolumn{2}{|c|}{2} \\
\hline & $\mu \max$ & G & $\mu \max$ & G & $\mu \max$ & G \\
\hline 0.2 & $0.53 \pm 0.05$ & $1.30 \pm 0.13$ & $0.27 \pm 0.02$ & $2.55 \pm 0.25$ & $0.25 \pm 0.02$ & $2.76 \pm 0.27$ \\
\hline 0.5 & $0.49 \pm 0.04$ & $1.40 \pm 0.14$ & $0.22 \pm 0.02$ & $3.13 \pm 0.31$ & $0.22 \pm 0.02$ & $3.13 \pm 0.31$ \\
\hline 1 & $0.17 \pm 0.01$ & $4.05 \pm 0.40$ & $0.19 \pm 0.02$ & $3.63 \pm 0.36$ & $0.20 \pm 0.02$ & $3.13 \pm 0.31$ \\
\hline
\end{tabular}

The combination of $1.5 \%$ alginate and $1 \% \mathrm{CaCl}_{2}$ as well as all the combinations with $2 \%$ alginate were the best because they maintained the stability of the beads during the 10 days of culture. However, the lowest number of free cells detected in the medium at the end of culture was recorded with the combination of $2 \%$ alginate and $1 \% \mathrm{CaCl}_{2}$. As a result, these alginates and $\mathrm{CaCl}_{2}$ concentrations were determined as the optimal conditions for the immobilization of microalgae and will be used in the following work. An observation of the beads made under these conditions and containing R. subcapitata cells in the exponential phase of growth, was carried out using a stereomicroscope (SteREO Discovery.V8) (Figure 4), equipped with a low-magnification objective $(G \times 1.0)$ and image capture software (Zen 2.3 lite, blue edition). 


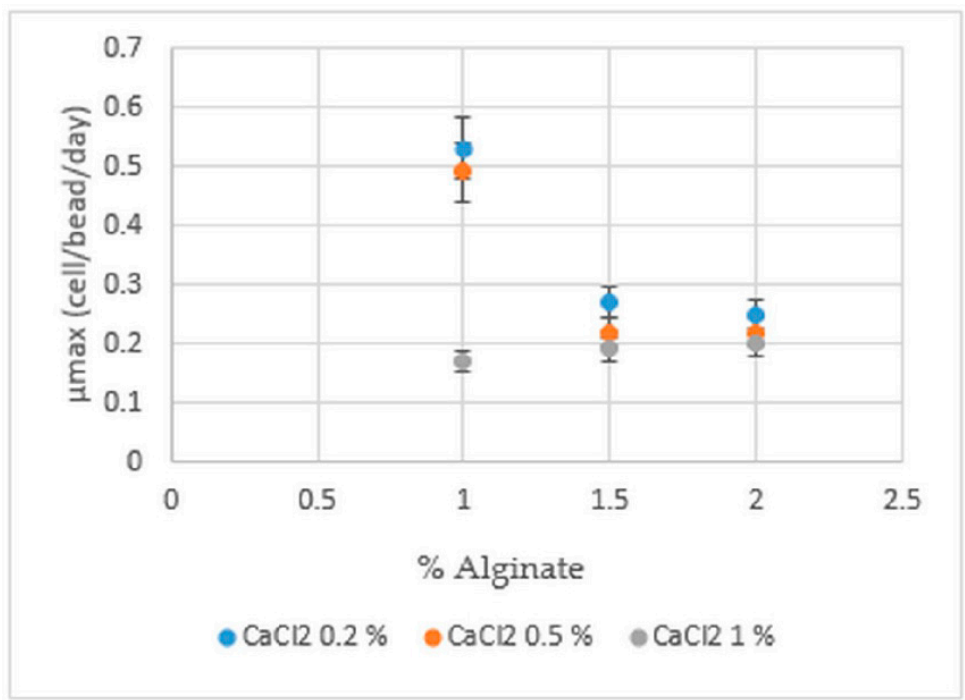

Figure 3. Variations in Growth Rates of Immobilized R. subcapitata depending on the alginate and $\mathrm{CaCl}_{2}$ concentrations studied. The growth rates decrease with increasing alginate and $\mathrm{CaCl}_{2}$ concentrations.

The growth value of $R$. subcapitata obtained in this study under the optimal conditions of immobilization $\left(2 \%\right.$ alginate and $\left.1 \% \mathrm{CaCl}_{2}\right)$ was higher than the values reported in other articles. Li-Juan Zhang et al. [46] obtained a growth of $18.5 \times 10^{4} \pm 0.3$ cells $/ \mathrm{mL}$ under the optimal immobilization conditions, which were determined to be $4 \%$ alginate and $\mathrm{CaCl}_{2}$, after three days of culture. If the growth value of the study presented here is converted into the same unit, it gives a growth of $34.3 \times 10^{4} \pm 0.34$ cells $/ \mathrm{mL}$ after three days of culture.

The differences in the growth values observed in the study of Li-Juan Zhang et al. [46] could be attributed to the alginate and $\mathrm{CaCl}_{2}$ concentrations used. The researchers used concentrations higher than what is proposed in this paper because their objective was to obtain dissolution-resistant beads in contaminated freshwater sediments.

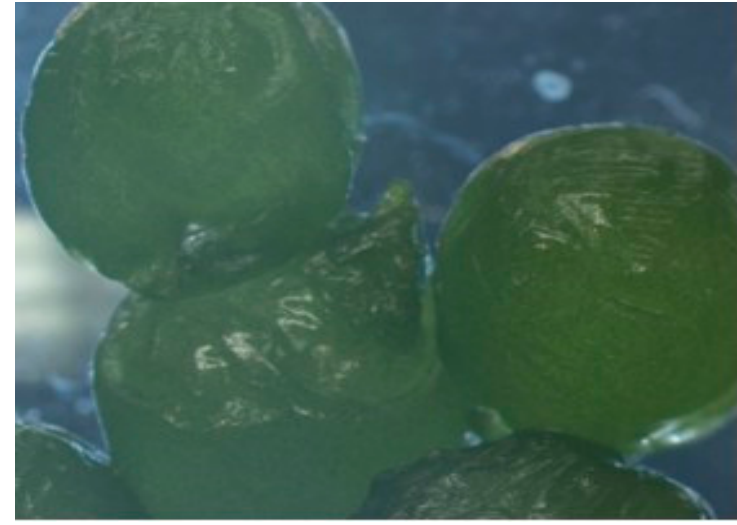

(a)

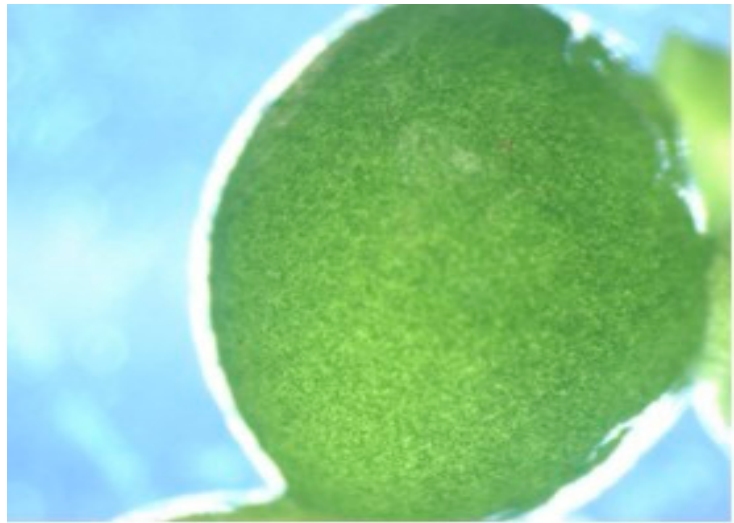

(b)

Figure 4. Beads formed from $2 \%$ alginate and $1 \% \mathrm{CaCl}_{2}$ containing $R$. subcapitata in the exponential growth phase. Stereomicroscope observation $(\mathrm{G} \times 1.0)$.

\subsection{Comparison of Free and Immobilized R. subcapitata Growth in Alginate Beads}

A comparison was established with the cells immobilized on the beads using $2 \%$ alginate and $1 \% \mathrm{CaCl}_{2}$ (Figure 5). The results obtained showed that the cell division termination is almost concomitant in both culture conditions. Nevertheless, the final concentration of cells is greater in the free culture $\left(7.1 \times 10^{6} \pm 0.71\right.$ cells $/ \mathrm{mL}$ against $1.52 \times 10^{6} \pm 0.15$ cells $/ \mathrm{mL}$ for the immobilized culture) . 
The immobilized cells expressed a growth rate of $0.203 \pm 0.02$ cells $/ \mathrm{mL} /$ day during the exponential phase of growth, while the free cells had a growth rate of $0.305 \pm 0.03$ cells $/ \mathrm{mL} /$ day. This is a decrease in the order of $34.42 \%$. These results first confirmed that immobilization in natural polysaccharides often causes material transfer limitations, which has been described in the literature [32]. Moreover, in the free culture, the suspension of algae in fermentation is homogeneous at any point of the reactor. In contrast, in the immobilized culture, the distribution of the alginate beads in the reactor and the distribution of the cells in the beads are heterogenous.

However, it should be noted that the use of immobilization technology in microalgae culture has made it easier to separate the cells from the water. The alginate beads are relatively large compared to free cells and can be easily collected through a simple filtration method such as sieving without a significant amount of energy consumed. In addition, although $R$. subcapitata was incubated under standard microalgal culture conditions, its growth exhibited better results than was found in the literature [46]. This research therefore suggests that optimizing the conditions of culture could provide even more promising results.

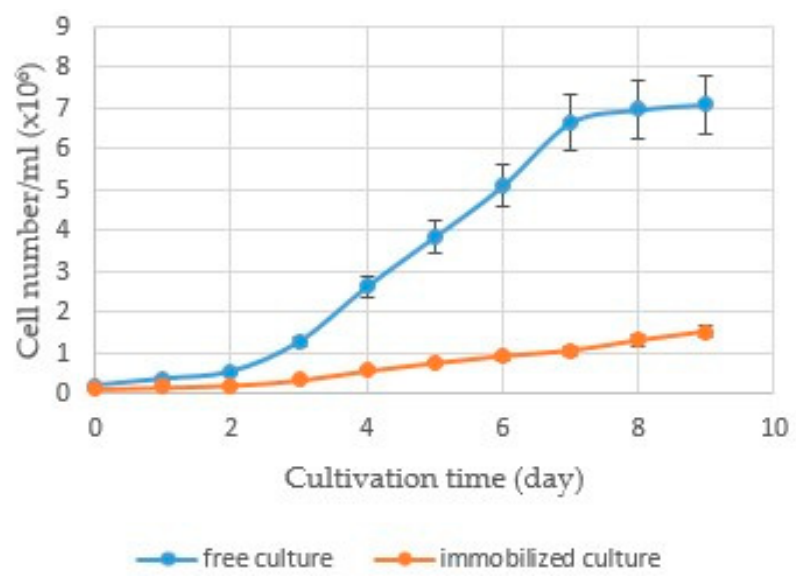

Figure 5. Growth of free and immobilized R. subcapitata in the Erlenmeyer flask for 10 days. The growth of the free seaweed follows a traditional pattern of a discontinuous culture. $t=0$ corresponds to the first day of culture.

\section{Conclusions}

This research studied the effects of immobilization conditions on the growth of Raphidocelis subcapitata in alginate beads. The first step was designed to determine the alginate and $\mathrm{CaCl}_{2}$ concentrations that are capable of generating beads. Following the results obtained, it was shown that among all the concentrations tested, only the concentrations of $1 \%, 1.5 \%$ and $2 \%$ alginate allowed us to obtain macroscopically homogeneous beads and had easy handling. Regardless of the concentration of $\mathrm{CaCl}_{2}$ used, the $2.5 \%$ alginate concentration generated irregular beads, while the $3 \%$ alginate was too viscous and insoluble in water. Therefore, these last two concentrations of alginate were considered inadequate for the elaboration of the beads.

The results of growth monitoring of the alga in the beads synthesized from different formulations showed that the highest growth $\left(3.92 \times 10^{6} \pm 0.39\right.$ cells/bead) was obtained with the combination of $1.5 \%$ alginate and $0.2 \% \mathrm{CaCl}_{2}$. However, these concentrations did not maintain the stability of the beads during the 10 days of culture. For a long-lasting microalgae culture, the optimal immobilization conditions were determined to be concentrations of $2 \%$ alginate and $1 \% \mathrm{CaCl}_{2}$. This choice is justified by the stability of the beads vis-à-vis the dissolution of the gel and the release of cells in the culture medium. The maximum concentration of cells reached in these beads was $3.04 \times 10^{6} \pm 0.3 \mathrm{cells} / \mathrm{bead}$ with a growth rate of $0.20 \pm 0.02$ cells/bead/day.

The results obtained are encouraging as the concentrations of cells reached are high compared to other works despite the fact that the strain was incubated under standard microalgal culture conditions. 
This study suggests that optimizing crop conditions, such as light, could lead to even more promising results. It is known that photon input is critical for microalgae culture in terms of biomass yield. Thus, it would be interesting to evaluate the influence of cell trapping in the alginate beads on light penetration. Although the gel is transparent and we have noted a considerable growth of algae, it can be a barrier and reduce the amount of light available.

On the other hand, further studies are needed to provide more information for the valorization of the immobilized Raphidocelis subcapitata biodiesel, namely the influence of cell trapping on biomass production and lipid production.

Thus, the contribution of the present work is paving the way for a possible use of a well-known algae for the production of biofuels. Despite the species having been studied before, this study allowed us to develop the knowledge on its culture in the alginate gel. This research is the first in the process of optimizing the growth of immobilized Raphidocelis subcapitata.

Author Contributions: A.B. and R.H. designed and developed the study. A.B. performed the experiments, collected and analyzed the data and drafted the manuscript. R.H. supervised the work, provided advice on methodology and results, and revised the manuscript.

Acknowledgments: We would like to thank the Natural Sciences and Engineering Research Council of Canada (NSERC) for funding this research.

Conflicts of Interest: The authors declare no conflict of interest.

\section{References}

1. Labriet, M.; Waaub, J.-P.; Prades, J.A. Stratégies de gestion des gaz à effet de serre au Québec: Grandes lignes et enseignements d'une recherche interdisciplinaire rapport de recherche. Nat. Sci. Soc. 2000, 8, 68-75. [CrossRef]

2. Petit, M. L'humanité face à l'effet de serre additionnel qu'elle crée. C. R. Acad. Sci. Ser. IIA Earth Planet. Sci. 2001, 333, 775-786. [CrossRef]

3. André, J.-C. Sur la crédibilité des conséquences de l'effet de serre. C. R. Geosci. 2003, 335, 503-507. [CrossRef]

4. Tissot, B. Quel avenir pour les combustibles fossiles? Les avancées scientifiques et technologiques permettront-elles la poursuite d'un développement soutenable avec les énergies carbonées? C. R. Acad. Sci. Ser. IIA Earth Planet. Sci. 2001, 333, 787-796. [CrossRef]

5. Lorius, C. Effet de serre: Les lacunes du savoir et de la perception. C. R. Geosci. 2003, 335, 545-549. [CrossRef]

6. Gavrilescu, M.; Chisti, Y. Biotechnology-A sustainable alternative for chemical industry. Biotechnol. Adv. 2005, 23, 471-499. [CrossRef] [PubMed]

7. Chisti, Y. Biodiesel from microalgae. Biotechnol. Adv. 2007, 25, 294-306. [CrossRef] [PubMed]

8. Khan, S.A.; Rashmi; Hussain, M.Z.; Prasad, S.; Banerjee, U.C. Prospects of biodiesel production from microalgae in India. Renew. Sustain. Energy Rev. 2009, 13, 2361-2372. [CrossRef]

9. Brennan, L.; Owende, P. Biofuels from microalgae-A review of technologies for production, processing, and extractions of biofuels and co-products. Renew. Sustain. Energy Rev. 2010, 14, 557-577. [CrossRef]

10. Lam, M.K.; Lee, K.T. Microalgae biofuels: A critical review of issues, problems and the way forward. Biotechnol. Adv. 2012, 30, 673-690. [CrossRef] [PubMed]

11. Cantin, I. La Production de Biodiesel à Partir des Microalgues Ayant un Métabolisme Hétérotrophe; Centre Universitaire de Formation en Environnement Université de Sherbrooke: Québec, QC, Canada, 2010.

12. Kadam, K.L. Environmental implications of power generation via coal-microalgae cofiring. Energy 2002, 27, 905-922. [CrossRef]

13. Doré-Deschênes, F. Utilisation des Microalgues Comme Source D'énergie Durable; Université de Sherbrooke: Québec, QC, Canada, 2009.

14. Molino, A.; Larocca, V.; Chianese, S.; Musmarra, D. Biofuels Production by Biomass Gasification: A Review. Energies 2018, 11, 811. [CrossRef]

15. Sialve, B.; Bernet, N.; Bernard, O. Anaerobic digestion of microalgae as a necessary step to make microalgal biodiesel sustainable. Biotechnol. Adv. 2009, 27, 409-416. [CrossRef] [PubMed]

16. Carver, S.M.; Hulatt, C.J.; Thomas, D.N.; Tuovinen, O.H. Thermophilic, anaerobic co-digestion of microalgal biomass and cellulose for $\mathrm{H}_{2}$ production. Biodegradation 2011, 22, 805-814. [CrossRef] [PubMed] 
17. Mussgnug, H.; Klassen, V.; Schlüter, A.; Kruse, O. Microalgae as substrates for fermentative biogas production in a combined biorefinery concept. J. Biotechnol. 2010, 150, 51-56. [CrossRef] [PubMed]

18. Scott, S.A.; Davey, M.P.; Dennis, J.S.; Horst, I.; Howe, C.J.; Lea-Smith, D.J.; Smith, A.G. Biodiesel from algae: Challenges and prospects. Curr. Opin. Biotechnol. 2010, 21, 277-286. [CrossRef] [PubMed]

19. Pienkos, P.T.; Darzins, A. The promise and challenges of microalgal-derived biofuels. Biofuels Bioprod. Biorefin. 2009, 3, 431-440. [CrossRef]

20. Lee, J.-Y.; Yoo, C.; Jun, S.-Y.; Ahn, C.-Y.; Oh, H.-M. Comparison of several methods for effective lipid extraction from microalgae. Bioresour. Technol. 2010, 101, S75-S77. [CrossRef] [PubMed]

21. Suali, E.; Sarbatly, R. Conversion of microalgae to biofuel. Renew. Sustain. Energy Rev. 2012, 16, 4316-4342. [CrossRef]

22. Sander, K.; Murthy, G.S. Life cycle analysis of algae biodiesel. Int. J. Life Cycle Assess. 2010, 15, 704-714. [CrossRef]

23. Moreira, S.M.; Moreira-Santos, M.; Guilhermino, L.; Ribeiro, R. Immobilization of the marine microalga Phaeodactylum tricornutum in alginate for in situ experiments: Bead stability and suitability. Enzyme Microb. Technol. 2006, 38, 135-141. [CrossRef]

24. Cao, Y.R.; Liu, Z.; Cheng, G.L.; Jing, X.B.; Xu, H. Exploring single and multi-metal biosorption by immobilized spent Tricholoma lobayense using multi-step response surface methodology. Chem. Eng. J. 2010, 164, 183-195. [CrossRef]

25. Moreno-Garrido, I. Microalgae immobilization: Current techniques and uses. Bioresour. Technol. 2008, 99, 3949-3964. [CrossRef] [PubMed]

26. Dulieu, C.; Poncelet, D.; Neufeld, R.J. Encapsulation and immobilization techniques. Cell Encapsul. Technol. Ther. 1999, 1, 1-17.

27. Draget, K.I.; Steinsvåg, K.; Onsøyen, E.; Smidsrød, O. Na- and K-alginate; effect on Ca ${ }^{2+}$-gelation. Carbohydr. Polym. 1998, 35, 1-6. [CrossRef]

28. Ruiz-Marin, A.; Mendoza-Espinosa, L.G. Ammonia removal and biomass characteristics of alginateimmobilized Scenedesmus obliquus cultures treating real wastewater. Fresenius Environ. Bull. 2008, 17, 1236-1241.

29. Lopez, B.R.; Hernandez, J.-P.; Bashan, Y.; de-Bashan, L.E. Immobilization of microalgae cells in alginate facilitates isolation of DNA and RNA. J. Microbiol. Methods 2017, 135, 96-104. [CrossRef] [PubMed]

30. Moreno-Garrido, I.; Campana, O.; Lubián, L.M.; Blasco, J. Calcium alginate immobilized marine microalgae: Experiments on growth and short-term heavy metal accumulation. Mar. Pollut. Bull. 2005, 51, 823-829. [CrossRef] [PubMed]

31. Antal, T.K.; Kukarskikh, G.P.; Volgusheva, A.A.; Krendeleva, T.E.; Tyystjärvi, E.; Rubin, A.B. Hydrogen photoproduction by immobilized S-deprived Chlamydomonas reinhardtii: Effect of light intensity and spectrum, and initial medium pH. Algal Res. 2016, 17, 38-45. [CrossRef]

32. Amsden, B. Solute diffusion in hydrogels: An examination of the retardation effect. Polym. Gels Netw. 1998, 6, 13-43. [CrossRef]

33. Patil, V.; Källqvist, T.; Olsen, E.; Vogt, G.; Gislerød, H.R. Fatty acid composition of 12 microalgae for possible use in aquaculture feed. Aquac. Int. 2007, 15, 1-9. [CrossRef]

34. Gonçalves, A.L.; Pires, J.C.; Simões, M. Lipid production of Chlorella vulgaris and Pseudokirchneriella subcapitata. Int. J. Energy Environ. Eng. 2013, 4, 14. [CrossRef]

35. Pires, J.C.M.; Gonçalves, A.L.; Martins, M.C.M.; Alvim-Ferraz, M.; Simões, M. Effect of light supply on $\mathrm{CO}_{2}$ capture from atmosphere by Chlorella vulgaris and Pseudokirchneriella subcapitata. Mitig. Adapt. Strateg. Glob. Chang. 2014, 19, 1109-1117. [CrossRef]

36. Polona, S.; Marija, B.; Anamarija, Z.; Odon, P.; Ales, M. Shape optimization and characterization of polysaccharide beads prepared by ionotropic gelation. J. Microencapsul. 2007, 25, 90-105.

37. Panouillé, M.; Larreta-Garde, V. Gelation behaviour of gelatin and alginate mixtures. Food Hydrocoll. 2009, 23, 1074-1080. [CrossRef]

38. Khromova, Y.L. The effect of chlorides on alginate gelation in the presence of calcium sulfate. Colloid J. 2006, 68, 115-119. [CrossRef]

39. Série de la Protection de L'environnement. Méthode D'essai Biologique: Essai D'inhibition de la Croissance d'une Algue d'eau Douce. Centre des Sciences et Technologies Environnementales; Environnement et Changement Climatique Canada: Ottawa, ON, Canada, 2007. 
40. Santos, M.M.D.; Moreno-Garrido, I.; Gonçalves, F.; Soares, A.M.; Ribeiro, R. An in situ bioassay for estuarine environments using the microalga Phaeodactylum tricornutum. Environ. Toxicol. Chem. 2002, 21, 567-574. [CrossRef] [PubMed]

41. Voo, W.-P.; Lee, B.-B.; Idris, A.; Islam, A.; Tey, B.-T.; Chan, E.-S. Production of ultra-high concentration calcium alginate beads with prolonged dissolution profile. RSC Adv. 2015, 5, 36687-36695. [CrossRef]

42. Richmond, A. Handbook of Microalgal Culture: Biotechnology and Applied Phycology; John Wiley \& Sons: Hoboken, NJ, USA, 2008.

43. Boyaval, P.; Lebrun, A.; Goulet, J. Etude de l'immobilisation de Lactobacillus helveticus dans des billes d'alginate de calcium. Le Lait 1985, 65, 185-199. [CrossRef]

44. Prevost, H.; Divies, C.; Rousseau, E. Continuous yoghurt production with Lactobacillus bulgaricus and Streptococcus thermophilus entrapped in Ca-alginate. Biotechnol. Lett. 1985, 7, 247-252. [CrossRef]

45. Prevost, H.; Divies, C. Fresh fermented cheese production with continuous pre-fermented milk by a mixed culture of mesophilic lactic streptococci entrapped in Ca-Al ginate. Biotechnol. Lett. 1987, 9, 789-794. [CrossRef]

46. Zhang, L.J.; Ying, G.G.; Chen, F.; Zhao, J.L.; Wang, L.; Fang, Y.X. Development and application of whole-sediment toxicity test using immobilized freshwater microalgae Pseudokirchneriella subcapitata. Environ. Toxicol. Chem. 2012, 31, 377-386. [CrossRef] [PubMed]

(C) 2018 by the authors. Licensee MDPI, Basel, Switzerland. This article is an open access article distributed under the terms and conditions of the Creative Commons Attribution (CC BY) license (http:/ / creativecommons.org/licenses/by/4.0/). 